\title{
FAKTOR-FAKTOR YANG DAPAT MEMENGARUHI PENERAPAN SERTIFIKASI KEBERLANJUTAN DI KALANGAN PETANI SWADAYA DI KECAMATAN SECANGGANG
}

\section{FACTORS THAT MAY INFLUENCE THE IMPLEMENTATION OF SUSTAINABILITY CERTIFICATION AMONG INDEPENDENT FARMERS IN SECANGGANG DISTRICT}

\author{
Prisman A. L. Sihombing*1, Maman. H. Karmana ${ }^{2}$ Ernah $^{2}$ \\ ${ }^{1}$ Pascasarjana Fakultas Pertanian, Universitas Padjadjaran \\ ${ }^{2}$ Fakultas Pertanian, Universitas Padjadjaran \\ *E-mail: andrilesmana276@gmail.com \\ (Diterima 22-07-2021; Disetujui 15-12-2021)
}

\begin{abstract}
ABSTRAK
Salah satu faktor penting meningkatnya konsumsi minyak sawit di Indonesia karena minyak kelapa sawit merupakan bahan utama pembuatan minyak goreng. Tujuan penelitian ini adalah mendeskripsikan faktor yang dapat memengaruhi penerapan sertifikasi keberlanjutan pada petani swadaya di Kecamatan Secanggang. Metode penelitian menggunakan survey, Pengambilan sampel dalam penelitian ini menggunakan sampel acak (Random Sampling) dengan jumlah responden 258 orang petani swadaya. Analisis data menggunakan Analisis Regresi Logistik Binear dengan model regresi logit. Hasil penelitian menunjukkan bahwa faktor internal yang dapat memengaruhi penerapan sertifikasi keberlanjutan perkebunan kelapa sawit di kalangan petani swadaya di Kecamatan Secanggang adalah umur petani, pengalaman bertani kelapa sawit, jumlah tanggungan keluarga dan pendapatan usahatani kelapa sawit; sedangkan faktor eksternal yang dapat memengaruhi penerapan sertifikasi keberlanjutan perkebunan kelapa sawit adalah akses informasi.
\end{abstract}

Kata kunci: kelapa sawit, swadaya, keberlanjutan

\begin{abstract}
One of the important factors in increasing consumption of palm oil in Indonesia is because palm oil is the main ingredient for making cooking oil. The purpose of this study is to describe the factors that can affect the implementation of sustainability certification on independent smallholders in Secanggang District. The research method uses a survey. Sampling in this study uses a random sample (Random Sampling) with the number of respondents as many as 258 independent farmers. Data analysis used Binary Logistics Regression Analysis with logit regression model. The results showed that the internal factors that could influence the implementation of oil palm plantation sustainability certification among independent smallholders in Secanggang District were Farmer Age, Oil Palm Farming Experience, Number of Family Dependents and Oil Palm Farming Income, while external factors that could affect the implementation of plantation sustainability certification palm oil is Access to Information.
\end{abstract}

Keywords: palm oil, self-help, sustainability

\section{PENDAHULUAN}

Prospek perkembangan industri kelapa sawit saat ini sangat pesat sejalan dengan peningkatan luas areal perkebunan kelapa sawit. Cerahnya prospek komoditas kelapa sawit dalam 
perdagangan minyak nabati mendorong pemerintah Indonesia untuk memacu pengembangan areal perkebunan kelapa sawit. Menurut Food and Agriculture Organization (FAO, 2018), Indonesia adalah negara produsen kelapa sawit terbesar di ASEAN maupun dunia dan sekaligus menjadi negara eskportir terbesar. Hal ini secara otomatis menjadikan Indonesia adalah negara dengan luasan lahan perkebunan kelapa sawit terbesar di dunia (Dirjenbun, 2019). Fenomena ini didasari oleh syarat tumbuh kelapa sawit yang sangat sesuai dengan Indonesia. Kelapa sawit tumbuh dengan baik pada dataran rendah di daerah tropis yang beriklim basah, yaitu sepanjang garis khatulistiwa antara $23.5^{\circ}$ lintang utara sampai $23,5^{\circ}$ lintang selatan dan merupakan faktor pendukung pesatnya perkembangan luasan areal perkebunan kelapa sawit di Indonesia (Pahan, 2007)

Direktorat Jendral Perkebunan menyatakan tahun 2018 perkebunan kelapa sawit di Indonesia mencapai 14.326.350 hektar. Dari luasan tersebut, $55.09 \%$ atau seluas 7.892 .706 hektar diusahakan oleh Perusahaan Besar Swasta (PBS), 40.62\% atau seluas 5.818.888 ha diusahakan oleh Perkebunan Rakyat (PR), dan 4.29\% diusahakan oleh Perkebunan Besar
Negara (PBN). Berdasarkan data Dirjenbun, PBS mengalami peningkatan paling tinggi pada periode tahun 20162017 dengan total kenaikan 14\% atau seluas 1.957 .968 juta hektar. PR juga mengalami peningkatan paling besar di periode tersebut sekitar $9 \%$ atau seluas 958.574 ribu ha. Berbeda dengan PBS dan PR, perkembangan luas areal perkebunan kelapa sawit untuk PBN dalam periode 10 tahun terahir terlihat sangat fluktuatif (turun-naik). Dirjenbun memprediksi tahun 2020 luas perkebunan kelapa sawit di Indonesia meningkat $0,9 \%$ atau seluas 271.590 ribu hektar.

Perkebunan kelapa sawit memberikan pendapatan yang besar untuk pemerintah pusat dan pemerintah daerah berdampak wilayah hutan banyak dialokasikan untuk pengembangan kelapa sawit terutama di Sumatera dan Kalimantan (Casson, 2000 dalam (Agustina \& Hariyadi, 2014). Perkembangan luas areal perkebunan kelapa sawit yang sangat pesat untuk memenuhi permintaan pasar global juga domestik ternyata menimbulkan berbagai permasalahan. Peningkatan luas areal perkebunan kelapa sawit yang sangat cepat dikhawatirkan mengabaikan prinsip-prinsip keberlanjutan yang berpotensi menyumbang kontribusi pada 
hilangnya tutupan kawasan hutan, kehilangan keanekaragaman hayati (biodiversity) dan terganggunya keseimbangan ekosistem, serta meningkatnya emisi gas rumah kaca dan menimbulkan konflik sosial dengan masyarakat sekitar perkebunan (Rizal et al., 2018). Ekspansi kelapa sawit secara langsung menyumbang $11 \%$ dari deforestasi Indonesia antara tahun 2000 dan 2010 (Abood et all, 2014). Ekspansi lahan perkebunan kelapa sawit adalah kata-kunci yang penting untuk mulai memahami semesta persoalan kelapa sawit di Indonesia (Dharmawan et al., 2019). World Growth menyatakan industri kelapa sawit Indonesia mendapat kecaman dari sejumlah Lembaga Swadaya Masyarakat (LSM) yang berkampanye menentang industri ini. Inti kecaman adalah ekspansi perkebunan yang dinilai berlangsung dalam waktu cepat dan massive. Sejalan dengan hal itu, muncul tudingan yang meluas bahwa industri minyak kelapa sawit sebagai komoditas yang tidak mendukung keberlanjutan (unsustainable).

Provinsi Sumatera Utara adalah salah satu sentra penghasil kelapa sawit di Indonesia. Secara histories perkebunan kelapa sawit pertama di Indonesia berlokasi di Sumatera Utara tepatnya
Pantai Timur Sumatera (Deli) dengan luas areal perkebunan 5.123 hektar, maka tak asing jika Sumatera Utara termasuk sentra penghasil kelapa sawit di Indonesia. Menurut data Dirjenbun tahun 2019, total luas areal perkebunan kelapa sawit di Sumatera Utara mencapai 1.630.744 juta hektar. PBN mengalami perkembangan paling tinggi pada periode 2015-2016 dengan total kenaikan 4,3\% atau seluas 30.635 ribu hektar. PR mengalami perkembangan paling tinggi pada periode 2017-2018 dengan total kenaikan 19\% atau seluas 222.599 ribu hektar. PBS mengalami perkembangan paling tinggi pada periode 2016-2017 dengan total kenaikan $18 \%$ atau seluas 247.044 ribu hektar.

Produk kelapa sawit merupakan salah satu komoditas pertanian yang sering mendapat perhatian terhadap pemenuhan kriteria keberlanjutan oleh konsumen. Masyarakat dunia khususnya konsumen menyambut positif himbauan melakukan produksi secara berkelanjutan, untuk menciptakan iklim produksi yang baru dan mendukung produksi barang yang memiliki jaminan berkelanjutan. Sektor pertanian di Indonesia juga menjadi sasaran penerapan praktik-praktik berkelanjutan. Mekanisme agribisnis yang berkelanjutan 
harus diciptakan sedemikian rupa untuk menciptakan iklim bisnis yang mampu diterima sehingga produk pertanian tidak kehilangan pasarnya akibat kehilangan kepercayaan dari konsumen (Saragih dkk, 2020).

Kecamatan Secanggang adalah salah satu kecamatan dari 23 kecamatan sentra penghasil kelapa sawit di Kabupaten Langkat. Berdasarkan data Dinas Perkebunan Sumatera Utara luas areal perkebunan kelapa sawit rakyat di wilayah ini mencapai 1.189 ha dengan populasi petani berjumlah $730 \mathrm{kk}$ petani dan belum terdaftar sebagai anggota koperasi atau kelompok tani. Perkebunan kelapa sawit rakyat di kawasan ini dikelola oleh petani swadaya dan mayoritas petani memiliki luasan lahan 10 ha. Berdasarkan hasil pra survey, perkebunan kelapa sawit rakyat di Kecamatan Secanggang Petani Swadaya di wilayah ini belum menerapkan Sertifikasi ISPO ataupun sertifikasi keberlanjutan lainnya. Sistem pemasaran hasil panen kelapa sawit tidak terorganisir, petani langsung menjual hasil panen ke Tengkulak dengan harga yang murah dengan kesepakatan jual beli TBS (Tandan Buah Segar) hanya dilakukan secara lisan menyebabkan posisi tawar (bargaining position) petani di Kecamatan Secanggang sangat rendah. Rata-rata petani swadaya di Secanggang tidak mengetahui pentingnya menjaga kelestarian lingkungan dan biodiversity. Ditemukan beberapa petani swadaya menggunakan bibit turunan atau yang tidak bersertifikat.

Analisis (Nora et al., 2020) menyatakan masyarakat di Kecamatan Secanggang menanam komoditas pertanian maupun perkebunan tanpa pertimbangan kecocokan lahannya dengan persyaratan tumbuh tanaman. Diduga petani kelapa sawit di Secanggang memiliki pengetahuan yang minim tentang budidaya perkebunan kelapa sawit sesuai Good Agricultural Practice akibat proses peralihan mata pencaharian dari pengusaha tambak udang kemudian menjadi petani kelapa sawit. Kerusakan mangrove di Kecamatan Secanggang terus mengalami peningkatan dan sudah mencapai tingkat yang cukup parah yang salah satunya diakibatkan oleh alih fungsi lahan mangrove menjadi kebun kelapa sawit (Dinas Perikanan dan Kelautan Kabupaten Langkat, 2002) dalam (Rosni, 2009). Penelitian yang dilakukan (Supriana, 2010) menunjukkan bahwa faktor sosial (tingkat pendidikan, tingkat pengetahuan lingkungan dan tingkat 
kosmopolitan) masyarakat berpengaruh nyata terhadap tingkat perambahan hutan mangrove di Kecamatan Secanggang.

Perkebunan kelapa sawit rakyat adalah bagian dari rantai pasok agribisnis kelapa sawit yang perlahan dituntut untuk menerapkan aspek keberlanjutan. Sertifikasi keberlanjutan seakan menjadi kewajiban untuk memasuki pasar sementara posisi perkebunan yang tidak memiliki kemampuan manajerial menjadi keterbatasan bagi petani (Saragih, 2020). Persoalan yang dihadapi oleh petani swadaya diperkirakan akan melambat manakala sertifikasi keberlanjutan kelapa sawit dapat diimplementasikan di lapangan (Dharmawan et al., 2019). Penerapan Sertifikasi keberlanjutan pada petani swadaya di Kecamatan Secanggang adalah solusi alternatif untuk menuju perkebunan kelapa sawit berkelanjutan sesuai permintaan pasar dan turut serta meningkatkan profitabilitas petani. Namun demikian, implementasi sertifikasi keberlanjutan tidak mudah karena readiness to implement sertifikasi yang sangat rendah (Brandi et al., 2015).

Berdasarkan uraian sebelumnya maka fokus penelitian ini yaitu mendeskripsikan faktor yang dapat memengaruhi penerapan sertifikasi keberlanjutan pada petani swadaya di Kecamatan Secanggang.

\section{METODE PENELITIAN}

Desain yang digunakan dalam penelitian ini adalah kuantitatif. Penelitian ini dilakukan di Kecamatan Secanggang, Kabupaten Langkat, Sumatera Utara. Metode yang digunakan dalam penelitian adalah metode survey. Penentuan tempat penelitian dilakukan secara sengaja, dengan pertimbangan bahwa Kecamatan Secanggang merupakan kawasan lindung hutan mangrove Suaka Margasatwa Karang Gading dan Langkat Timur Laut (SM KGLTL) (Rosni, 2009). Jenis data yang digunakan dalam penelitian ini adalah data primer dan data sekunder. Pengambilan sampel dalam penelitian ini menggunakan sampel acak (Random Sampling) dengan jumlah responden 258 orang petani swadaya.

Analisis data menggunakan Analisis Regresi Logistik Binear dengan model regresi logit. Regresi Logistik adalah analisis statistika untuk mendeskripsikan hubungan antara peubah respon (dependent variable) yang memiliki dua kategori atau lebih dengan satu atau lebih peubah penjelas (independent variable) berskala kategori 
atau interval (Hosmer \& Lemeshow, 2000) dalam (Hendayana, 2013). Regresi Logistik merupakan regresi non linear, digunakan untuk menjelaskan hubungan antara variabel dependent dan variabel independent, keragaman respon tidak konstan yang tidak dapat dijelaskan dengan model regresi linear biasa (Hendayana, 2013). Penelitian ini bertujuan untuk menganalisis faktorfaktor yang dapat memengaruhi penerapan sertifikasi keberlanjutan oleh petani swadaya di Kecamatan Secanggang dengan variabel respon $y$ terdiri dari dua kategori yaitu "menerapkan" dan "tidak menerapkan" yang dinotasikan dengan $y=1$ (menerapkan) dan $\quad y=0 \quad$ (tidak menerapkan). Secara umum model regresi logit dapat ditulis sebagai berikut (Nachrowi dan Usman, 2005):

$\mathrm{Li}=\operatorname{Ln}\left[\frac{P i}{1-P}\right]=\beta 1+\beta 2 X i+U i$

(P/(1-P)) adalah odd ratio (perbandingan resiko) dimana $\mathrm{p}$ menyatakan probabilitas petani yang mau menerapkan sertifikasi keberlanjutan $(\mathrm{y}=1)$ dan $\mathrm{p}-1$ menyatakan probabilitas petani yang tidak mau menerapkan sertifkasi keberlanjutan $(\mathrm{y}=0)$.

Untuk melihat bagaimana pengaruh antara dependent variable dengan independent variable, berdasarkan pada model yang diterapkan oleh Nachrowi dan Usman (2005), maka digunakan model logit sebagai berikut: $\operatorname{Ln} \frac{P}{1-P}=\beta 0+\beta 1 \mathrm{X} 1+\beta 2 \mathrm{X} 2+\beta 3 \mathrm{X} 3+\beta 4 \mathrm{X} 4+\beta 5 \mathrm{X} 5 \ldots$.
B11X11+e. Dimana:

$\mathrm{P}=$ Probabilitas petani menerapkan sertifikasi keberlanjutan

$1-\mathrm{P}=$ Probabilitas petani tidak menerapkan sertifikasi keberlanjutan

$\beta 0=$ Konstanta

$\mathrm{X} 1=$ Umur Petani

$\mathrm{X} 2=$ Tingkat Pendidikan Formal

$\mathrm{X} 3$ = Pengalaman Bertani Kelapa Sawit

$\mathrm{X} 4=$ Luas Lahan

$\mathrm{X} 5$ = Produktivitas Kelapa Sawit

$\mathrm{X} 6=$ Jumlah Tanggungan Keluarga

$\mathrm{X} 7$ = Pendapatan Usahatani Kelapa Sawit

$\mathrm{X} 8=$ Sumber Pendapatan Lain

X9 = Status Kepemilikan Lahan

$\mathrm{X} 10=$ Penyuluhan

$\mathrm{X} 11=$ Akses Informasi

$\mathrm{E}=$ Kesalahan (Error term)

$\beta 1 \beta 2 \beta 3 \beta 4 \beta 5 \ldots \ldots \beta 11=$ Koefisien

a. Uji Kelayakan Model Goodness of Fit

Uji Goodness of fit digunakan untuk mengetahui ukuran ketepatan model yang dipakai yang dinyatakan dengan beberapa persen variabel dependent dapat dijelaskan oleh variabel independent yang dimasukkan kedalam model regresi. Model yang digunakan harus layak atau memenuhi Goodness of Fit (GoF). Menurut (Hendayana, 2013) suatu model dikategorikan memenuhi GoF jika terdapat kesesuaian antara data yang dimasukkan dalam model dengan data yang diamati. 


\section{b. Pengujian Parameter}

Model persamaan yang diperoleh perlu dilakukan pengujian signifikasi. Pengujian ini dimaksudkan untuk mengetahui apakah variabel yang terdapat dalam model memiliki kontribusi yang nyata bagi variabel respon. Pengujian yang dilakukan adalah:

1) Uji Omnibus (Serempak)

Dilakukan untuk memeriksa signifikasi parameter $\beta$ secara keseluruhan atau serentak. Hipotesis pengujian ini adalah:

Ho: $\beta$ o $=\beta 1=\ldots=\beta p=0$

H1: Paling tidak ada satu $\beta \mathbf{j} \neq 0, \mathrm{j}=1,2, . \mathrm{p}$

2) Uji Wald (Individu)

Dimaksudkan untuk memeriksa signifikasi parameter $\beta$ secara individu. Hipotesisnya adalah:

Ho: $\beta \mathrm{j}=0$

$\mathrm{H} 1: \beta \mathbf{j} \neq 1,2, \ldots, \mathrm{p}$

Dengan uji statistic:

$$
\mathrm{W}(\mathrm{Wald})=\left[\frac{\beta j}{\operatorname{S.E}(\beta j}\right]
$$

Daerah penolakan: Tolak Ho apabila $\mathrm{Wj}^{2}$ $>\mathrm{X}^{2} \alpha, 1$ atau $\mathrm{p}$ - value $<\alpha$

3) Uji Hosmer dan Lemeshow

Uji ini untuk membandingkan distribusi observasi dengan distribusi teori (uji model). Hipotesisnya adalah: Ho: $K=(1-B)=0$, Tidak ada perbedaan distribusi observasi dengan distribusi teori /model sesuai dengan data.
$\mathrm{H} 1: \mathrm{K}=(1-\mathrm{B}) \neq 0$, ada perbedaan distribusi observasi dengan distribusi teori/model tidak sesuai dengan data.

Kriteria pengujian:

Jika sign $<0,05$ maka terima H1 tolak Ho Jika sign $>0,05$ maka terima Ho tolak H1

4) Marginal Effect

Untuk menghitung perubahan peluang atas perubahan tertentu dari variabel independent dapat dihitung dengan menggunakan rumus:

$\frac{d P i}{d X i}=\beta \mathrm{iPi}(1-\mathrm{Pi})$

\section{HASIL DAN PEMBAHASAN}

Karakteristik Petani Kelapa Sawit Swadaya di Kecamatan Secanggang.

Responden dalam penelitian ini adalah petani swadaya perkebunan kelapa sawit. Menurut (Akhbianor et al., 2015), petani swadaya kelapa sawit adalah petani yang mengusahakan perkebunan kelapa sawit dengan kemampuan yang mereka miliki dari aspek biaya, pengelolaan sampai pemasaran hasil panen. (Andoko et al., 2013) menambahkan bahwa petani swadaya merupakan petani yang dengan inisiatif sendiri membuka dan mengelola lahan secara mandiri, tidak terkait dengan perusahaan tertentu. Petani responden dalam penelitian ini berjumlah 258 orang petani swadaya. 
Karateristik petani swadaya di Kecamatan Secanggang dijelaskan dengan analisis deskriptif dan diolah dengan cara dikelompokkan, ditabulasikan menggunakan frekuensi rata-rata kemudian diberi penjelasan naratif sehingga memberikan gambaran empiris dari data primer yang telah dikumpulkan dari responden yang terlibat secara langsung dengan kegiatan pengelolaan perkebunan kelapa sawit. Petani swadaya yang mengelola perkebunan kelapa sawit di Kecamatan Secanggang yang masuk sebagai responden dalam penelitian ini seluruhnya berjenis kelamin laki-laki. Kegiatan budidaya kelapa sawit merupakan kegiatan yang memiliki risiko yang tinggi dengan menggunakan porsir tenaga yang besar menjadi latar belakang fenomena tersebut. Karakteristik petani yang diamati dalam penelitian ini adalah umur, tingkat pendidikan, pengalaman dan jumlah tanggungan keluarga. Karakteristik terdiri dari 4 indikator yang dijelaskan secara lebih rinci pada Tabel 1.

Tabel 1 menjelaskan karateristik petani responden yaitu petani swadaya kelapa sawit yang terdiri atas umur, tingkat pendidikan, pengalaman bertani kelapa sawit dan jumlah tanggungan keluarga. Sebagian besar petani swadaya berada pada kisaran umur 42-52 tahun yaitu sebesar 34,11\%. Tingkat pendidikan petani swadaya sebagian besar adalah Sekolah Dasar (SD) dengan persentase sebesar 56,59\% dan pengalaman bertani kelapa sawit yang dimiliki petani swadaya 11-20 tahun atau sebesar 37,98\%. Jumlah tanggungan keluarga paling besar yang dimiliki petani swadaya kelapa sawit adalah tiga orang dengan persentase sebesar 29,46\%

Tabel 1. Presentase Karateristik Petani Swadaya

\begin{tabular}{|c|c|c|c|}
\hline Indikator & $\begin{array}{c}\text { Komponen } \\
\text { Karateristik Petani } \\
\text { Swadaya }\end{array}$ & $\begin{array}{l}\text { Jml. } \\
\text { (orang) }\end{array}$ & $\%$ \\
\hline $\begin{array}{l}\text { Umur } \\
\text { (tahun) }\end{array}$ & $\begin{array}{l}1=20-30 \text { tahun } \\
2=31-41 \text { tahun } \\
3=42-52 \text { tahun } \\
4=53-64 \text { tahun } \\
5=>64 \text { tahun } \\
\text { Jumlah }\end{array}$ & $\begin{array}{r}11 \\
52 \\
88 \\
78 \\
29 \\
258\end{array}$ & $\begin{array}{r}4,26 \\
20,16 \\
34,11 \\
30,23 \\
11,24 \\
\mathbf{1 0 0 . 0 0}\end{array}$ \\
\hline $\begin{array}{l}\text { Tingkat } \\
\text { Pendi- } \\
\text { dikan } \\
\text { Formal } \\
\text { (tahun) }\end{array}$ & $\begin{array}{l}1=\text { Tidak Sekolah } \\
2=\text { SD } \\
3=\text { SMP } \\
4=\text { SMA } \\
5=\text { Perguruan Tinggi } \\
\text { Jumlah }\end{array}$ & $\begin{array}{r}12 \\
146 \\
49 \\
42 \\
9 \\
258\end{array}$ & $\begin{array}{r}4,65 \\
56,59 \\
18,99 \\
16,28 \\
3,49 \\
\mathbf{1 0 0 . 0 0}\end{array}$ \\
\hline $\begin{array}{l}\text { Pengala- } \\
\text { man } \\
\text { (tahun) }\end{array}$ & $\begin{array}{l}1=0-10 \text { tahun } \\
2=11-20 \text { tahun } \\
3=21-30 \text { tahun } \\
4=31-40 \text { tahun } \\
5=>40 \text { tahun } \\
\text { Jumlah }\end{array}$ & $\begin{array}{r}63 \\
98 \\
60 \\
29 \\
8 \\
258\end{array}$ & $\begin{array}{r}24,42 \\
37,98 \\
23,26 \\
11,24 \\
3,10 \\
\mathbf{1 0 0 , 0 0}\end{array}$ \\
\hline $\begin{array}{l}\text { Jumlah } \\
\text { Tang- } \\
\text { gungan } \\
\text { Keluarga } \\
\text { (orang) }\end{array}$ & $\begin{array}{l}1=>4 \text { orang } \\
2=4 \text { orang } \\
3=3 \text { orang } \\
4=2 \text { orang } \\
5=<2 \text { orang } \\
\text { Jumlah }\end{array}$ & $\begin{array}{r}51 \\
58 \\
76 \\
73 \\
0 \\
258\end{array}$ & $\begin{array}{r}19,77 \\
22,48 \\
29,46 \\
28,29 \\
0 \\
\mathbf{1 0 0 , 0 0}\end{array}$ \\
\hline
\end{tabular}

Sumber: Data Primer (diolah)

Faktor yang Dapat Memengaruhi
Penerapan Sertifikasi Keberlanjutan Sertifikasi keberlanjutan perkebunan kelapa sawit adalah salah 
satu cara menanggulangi dampak lingkungan, permasalahan sosial, pemanasan global, pemusnahan dan dampak lainnya (Emilia et al., 2014). Emilia berpendapat sertifikasi produk kelapa sawit yang disyaratkan menimbulkan konsekuensi baru yang menuntut produk CPO yang diterima di pasar international haru berasal dari produksi yang tersertifikasi kelapa sawit mulai dari produk Tandan Buah Segar (TBS) sebagai bahan baku hingga menjadi CPO dan produk turunannya. Petani swadaya sebagai salah satu stakeholder produksi kelapa sawit diharapkan mampu menerapkan sertifikasi keberlanjutan kelapa sawit yang sudah ditetapkan. Penerapan sertifikasi keberlanjutan bertujuan untuk memelihara lingkungan, meningkatkan ekonomi, sosial dan penegakan peraturan perundang-undangan di Indonesia. Sertifikasi keberlanjutan diharapkan dapat diikuti oleh seluruh produsen kelapa sawit di Indonesia, namun karateristik perkebunan rakyat (smallholders) dengan berbagai keterbatasannya menghadapi kendala dalam memenuhi standar keberlanjutan tersebut.

Penelitian ini ingin melihat faktorfaktor yang dapat memengaruhi petani swadaya di Kecamatan Secanggang dalam menerapkan sertifikasi keberlanjutan perkebunan kelapa sawit. Analisis faktor-faktor yang dapat memengaruhi petani kelapa sawit swadaya dalam menerapkan sertifikasi keberlanjutan perkebunan kelapa sawit di Kecamatan Secanggang dilakukan menggunakan Regresi Logistik dengan Model logit. Hasil dari model tersebut diuji dengan menggunakan bantuan software SPSS 21. Secara keseluruhan model mampu mengklasifikasikan responden dalam memengaruhi penerapan sertifikasi keberkelanjutan, artinya model logit secara keseluruhan dapat menjelaskan faktor-faktor yang dapat memengaruhi petani kepala sawit swadaya di Kecamatan Secanggang dalam menerapkan sertifikasi keberlanjutan perkebunan kelapa sawit.

Faktor-faktor yang diduga dapat memengaruhi keputusan petani kelapa sawit swadaya dalam menerapkan sertifikasi keberlanjutan perkebunan kelapa sawit meliputi beberapa variabel independen yaitu umur, pengalaman bertani, tingkat pendidikan, luas lahan, produktivitas, tanggungan keluarga, total pendapatan, pendapatan lain, status kepemilikan lahan, penyuluhan dan akses informasi. Variabel dependen yaitu petani 
kelapa sawit swadaya menerapkan sertfikasi keberlanjutan kelapa sawit (Y). Penelitian ini menggunakan tingkat kepercayaan $95 \%$ atau taraf nyata 0,05 . Berikut analisis faktor-faktor yang dapat memengaruhi keputusan petani menerapkan sertifikasi keberlanjutan perkebunan kelapa sawit disajikan pada Tabel 2.

Tabel

2. Faktor-faktor yang dapat memengaruhi Petani Swadaya menerapkan sertifikasi keberlanjutan

\begin{tabular}{|c|c|c|c|}
\hline Variabel & B & P-value & $\begin{array}{c}\text { Odds } \\
\text { Ratio }\end{array}$ \\
\hline Konstan & 11,286 & & \\
\hline Umur Petani & 0,051 & 0,027 & 1,053 \\
\hline $\begin{array}{l}\text { Pengalaman Bertani } \\
\text { Kelapa Sawit }\end{array}$ & $-0,063$ & 0,003 & 0,939 \\
\hline Tingkat Pendidikan & 0,100 & 0,089 & 1,105 \\
\hline Luas Lahan & $-0,028$ & 0,151 & 0,972 \\
\hline $\begin{array}{l}\text { Produktivitas Kelapa } \\
\text { Sawit }\end{array}$ & 0,001 & 0,822 & 1,001 \\
\hline $\begin{array}{l}\text { Jumlah Tanggungan } \\
\text { Keluarga }\end{array}$ & 0,287 & 0,044 & 1,333 \\
\hline $\begin{array}{l}\text { Pendapatan } \\
\text { Usahatani Kelapa } \\
\text { Sawit }\end{array}$ & $-0,131$ & 0,001 & 0,877 \\
\hline $\begin{array}{l}\text { Sumber Pendapatan } \\
\text { Lain }\end{array}$ & $-0,103$ & 0,880 & 0,902 \\
\hline $\begin{array}{l}\text { Status Kepemilikan } \\
\text { Lahan }\end{array}$ & $-0,295$ & 0,205 & 0,183 \\
\hline Penyuluhan & $-0,555$ & 0,265 & 0,574 \\
\hline Akses Informasi & 2,045 & 0,000 & 7,729 \\
\hline Omnibus Test & & 90,076 & \\
\hline -2 Log Likelihood & & 224,449 & \\
\hline Prob $>$ Chisq & & 0,1 & \\
\hline Pseudo $\mathbf{R}^{2}$ & & 0,769 & \\
\hline
\end{tabular}

Sumber: Data Primer (diolah)

Berdasarkan Tabel 2, hasil pengujian uji serempak (Omnibus Test) model regresi logit menunjukkan bahwa model yang digunakan telah sesuai untuk model faktor-faktor yang dapat memengaruhi petani kelapa sawit swadaya dalam menerapkan sertifikasi keberlanjutan perkebunan kelapa sawit di Kecamatan Secanggang sebesar 90,076 $\%$, hal tersebut ditunjukkan dengan nilai ratio likelihood yang tinggi sebesar 224,449 (>10), yang berarti model uji yang telah dilakukan sangat bermanfaat.

Hasil pendugaan logit memiliki nilai prob $>$ Chisq $=0,1$ sehingga tolak H0 dan terima H1. Hasil pengujian serempak tersebut menunjukkan bahwa paling sedikit ada satu variabel independen yang berpengaruh nyata terhadap peluang petani kelapa sawit swadaya menerapkan sertifikasi keberlanjutan. Kemampuan variabel (umur, pengalaman bertani, tingkat pendidikan, luas lahan, produktivitas, tanggungan keluarga, total pendapatan, pendapatan, status kepemilikan lahan, penyuluhan dan akses informasi) dalam menjelaskan variabel dependen (menerapkan sertifikasi keberlanjutan) dapat dilihat dari nilai Pseudor $\mathrm{R}^{2}$.

Hasil pengujian nilai Pseudor $\mathrm{R}^{2}$ sebesar 0,769 menunjukan bahwa secara bersama-sama 11 (sebelas) variabel mampu menjelaskan pengaruh petani kepala sawit swadaya untuk berpeluang menerapkan ISPO sebesar 76,9\%. Selebihnya sebesar $23,1 \%$ dipengaruhi oleh faktor lain di luar model penelitian ini. 
Hasil pengujian parsial menggunakan Wald

Test diinterpretasikan dengan cara melihat nilai p-value pada masing-masing variabel independennya. Hasil pengujian menunjukan bahwa faktor yang signifikan dan berpengaruh terhadap faktor-faktor yang memengaruhi petani kelapa sawit swadaya menerapkan sertifikasi keberlanjutan yaitu: umur, pengalaman bertani, tanggungan keluarga, total pendapatan dan akses informasi. Berdasarkan hasil pengujian, maka didapatkan persamaan regresi logit faktor-faktor yang memengaruhi petani kelapa sawit swadaya berpeluang menerapkan sertifikasi keberlanjutan sebagai berikut:

$$
\begin{aligned}
\operatorname{Ln}=\left(\frac{p i}{1-p i}\right) 11, & 286+0,051 X_{1}-0,063 X_{2} \\
& +0,100 X_{3}-0,028 X_{4}+0,001 \\
& +0,287 X_{6}-0,131 X_{7}-0,103 X_{8} \\
& -0,295 X_{9}+0,555 X_{10} \\
& -2,045 X_{11}
\end{aligned}
$$

Variabel independen yang tidak signifikan dan tidak berpengaruh nyata terhadap berpeluang menerapkan sertifikasi keberlanjutan pada taraf nyata 5 persen $(\alpha=0,05)$ yaitu tingkat pendidikan, luas lahan, produktivitas, pendapatan dan penyuluhan sertifikasi keberlanjutan perkebunan kelapa sawit.

\section{Umur Petani}

Umur adalah aspek penting yang memengaruhi seseorang dalam melakukan usahatani kelapa sawit. Menurut Nurhasikin (2013) manusia dikatakan produktif apabila memiliki usia 15-64 tahun, dimana usia produktif merupakan usia ideal untuk bekerja dan mempunyai kemampuan untuk meningkatkan produktivitas kerja serta memiliki kemampuan untuk menyerap informasi dan teknologi yang inovatif di bidang pertanian. Data hasil penelitian menyatakan bahwa $88,76 \%$ petani swadaya di Kecamatan Secanggang berumur produktif.

Berdasarkan hasil Regresi Logistik, variabel umur petani menunjukkan nilai $P$-Value sebesar 0,02 yang menyatakan bahwa hasil ini $<0,05$ (taraf nyata $5 \%$ ) maka H0 diterima, artinya faktor umur petani memiliki pengaruh yang signifikan dan dapat memengaruhi petani kelapa sawit swadaya di Kecamatan Secanggang untuk menerapkan sertifikasi keberlanjutan perkebunan kelapa sawit. Hasil uji regresi logit terhadap variabel umur memiliki nilai koefisien positif sebesar 0,051 dengan nilai Odd Ratio umur petani sebesar 1,053 yang artinya jika umur petani naik satu tahun maka kemungkinan untuk menerapkan 
sertifikasi keberlanjutan perkebunan kelapa sawit naik sebesar 1,053. Hasil penelitian ini tidak sejalan dengan penelitian yang dilakukan oleh (Emilia et al., 2014) menyatakan bahwa faktor umur petani kelapa sawit tidak berpengaruh secara signifikan terhadap minat partisipasi petani KKPA dalam sertifikasi perkebunan kelapa sawit di Kabupaten Kampar.

\section{Pengalaman Bertani Kelapa Sawit}

Pengalaman merupakan salah satu faktor penting jika seseorang ingin mengadopsi atau menerapkan suatu kegiatan, pengalaman seseorang dalam berusahatani berpengaruh dalam menerima inovasi dari luar. (Soekartawi, 2003) berpendapat petani yang sudah lama berusahatani akan lebih mudah menerapkan inovasi atau teknologi dan mudah menjalankan anjuran dari para penyuluh. Lebih lanjut (Nurfitri, 2014) menyatakan jika petani yang telah lama terjun dalam usaha tani akan lebih mudah menerima perubahan-perubahan dalam usahatani karena pengalaman di lapangan yang relatif lebih banyak.

Hasil Regresi Logistik menyatakan bahwa variabel pengalaman bertani memperoleh nilai $p$-value sebesar $0,003<$ 0,05 (taraf nyata $5 \%$ ) yang menunjukkan H0 diterima, artinya variabel pengalaman bertani berpengaruh secara signifikan terhadap penerapan sertifikasi keberlanjutan kelapa sawit oleh petani swadaya di Kecamatan Secanggang. Berdasarkan uji regresi terhadap variabel pengalaman bertani memiliki nilai koefisien negatif sebesar -0,063. Nilai Odds Ratio variabel pengalaman bertani sebesar 0,939 yang menunjukkan bahwa jika pengalaman bertani naik satu tahun maka kemungkinan peluang petani swadaya naik sebesar 0,939 dalam menerapkan sertifikasi keberlanjutan perkebunan kelapa sawit di Kecamatan Secanggang. Rata-rata pengalaman petani swadaya di Kecamatan Secanggang dalam budidaya kelapa sawit adalah 1120 tahun. Menurut penelitian (Panjaitan et al., 2020) menyatakan faktor pengalaman bertani memengaruhi secara signifikan dalam meningkatkan produktivitas perkebunan kelapa sawit di Kabupaten Kuantan Singingi. Produktivitas perkebunan kelapa sawit yang baik merupakan tujuan dalam implementasi sertifikasi perkebunan kelapa sawit, maka sangat relevan jika pengalaman bertani menjadi faktor yang mendorong penerapan sertifikasi keberlanjutan perkebunan kelapa sawit di Kecamatan Secanggang. 


\section{Jumlah Tanggungan Keluarga}

Tanggungan keluarga adalah jumlah anggota keluarga petani yang kebutuhannya masih dipenuhi. Hasyim (2003) berpendapat dalam (Mandang et al., 2020) bahwa jumlah tanggungan keluarga merupakan salah satu faktor yang harus diperhatikan dalam menentukan pendapatan untuk memenuhi kebutuhannya. Banyaknya jumlah tanggungan berdampak mendorong petani untuk melakukan banyak aktivitas terutama dalam mencari dan menambah pendapatan keluarganya. Menurut (Soekartawi, 2003) jumlah anggota keluarga akan memengaruhi keputusan petani dalam berusahatani.

Hasil Regresi Logistik menghasilkan nilai $p$-value variabel luas lahan sebesar 0,044<0,05 (taraf nyata 5\%) yang menunjukkan H0 diterima, artinya tanggungan keluarga memiliki pengaruh yang signifikan terhadap penerapan sertifikasi keberlanjutan perkebunan kelapa sawit. Hasil uji regresi logit terhadap variabel tanggungan keluarga memiliki nilai koefisien positif sebesar 0,287. Nilai Odds Ratio variabel jumlah tanggungan keluarga sebesar 1,333 , yang menyatakan jika tanggungan keluarga petani bertambah 1 orang maka peluang kemungkinan menerapkan sertifikasi keberlanjutan perkebunan kelapa sawit naik sebesar 1,333. Dengan demikian dapat disimpulkan bahwa keluarga yang memiliki jumlah tanggungan lebih banyak lebih berpeluang menerapkan sertifikasi keberlanjutan kelapa sawit, hal ini dikarenakan dengan banyaknya jumlah anggota keluarga akan menambah jumlah tenaga kerja yang akan membantu jika sertifikasi keberlanjutan perkebunan kelapa sawit diterapkan. Dengan banyaknya persyaratan yang harus dipenuhi dalam sertifikasi keberlanjutan perkebunan kelapa sawit, akan sangat efisien jika dibantu oleh 1-4 tenaga kerja yang berasal dari keluarga. Hasil uji regresi logistik variabel jumlah tanggungan keluarga pada penelitian ini tidak sejalan dengan penelitian oleh (Emilia et al., 2014) yang menyatakan variabel jumlah tanggungan keluarga tidak berpengaruh secara signifikan dalam minat petani KKPA berpartisipasi dalam sertifikasi produk kelapa sawit di Kabupaten Kampar.

\section{Pendapatan Usahatani Kelapa Sawit}

Pendapatan usahatani kelapa sawit adalah imbalan atau balas jasa input-input produksi kelapa sawit yang diterima petani. Menurut (Ginting, 2016) pendapatan usahatani akan 
menguntungkan jika penerimaan total lebih besar daripada biaya usahatani dan sebaliknya. (Soekartawi, menambahkan jika pendapatan usahatani yang tinggi sangat berhubungan erat dengan difusi inovasi pertanian dan tingkat adopsi pertanian. Kemauan melakukan perubahan dalam difusi inovasi cenderung lebih cepat sesuai dengan kondisi pendapatan petani.

Hasil Regresi Logistik pada variabel pendapatan usahatani kelapa sawit menghasilkan nilai $p$-value sebesar $0,001<0,05$ (taraf nyata 5\%) yang menunjukkan H0 diterima, artinya variabel pendapatan usahatani kelapa sawit berpengaruh secara signifikan dan dapat memengaruhi penerapan sertifikasi keberlanjutan perkebunan kelapa sawit oleh petani swadaya di Kecamatan Secanggang. Nilai Odds Ratio variabel pendapatan usahatani kelapa sawit sebesar 0,877 artinya jika pendapatan yang diterima petani swadaya bertambah, maka nilai peluang penerapan sertifikasi keberlanjutan perkebunan kelapa sawit akan naik sebesar 0,877. Hasil uji Regresi Logistik ini sejalan dengan penelitian oleh (Gustina et al., 2020) yang mengemukakan bahwa faktor pendapatan memengaruhi secara signifikan keputusan petani swadaya di Desa Bukit Peninjauan
II untuk mengkonversi usahatani padi menjadi usahatani kelapa sawit.

Rata-rata pendapatan dari kelapa sawit yang diterima petani swadaya di lokasi penelitian berjumlah \pm 35 juta/ha/tahun. Fakta tersebut menunjukkan pendapatan petani swadaya tergolong rendah dan hanya cukup memenuhi kebutuhan pokok petani. Maka dapat disimpulkan untuk kebutuhan biaya sertifikasi dibutuhkan dukungan banyak kalangan seperti, lembaga keuangan, koperasi dan pemerintah daerah dalam memberi dukungan berupa bantuan dana untuk penerapan sertifikasi keberlanjutan perkebunan kelapa sawit.

\section{Akses Informasi}

Informasi adalah salah satu faktor penentu untuk seseorang dalam mengambil keputusan (Putri \& Purnomo, 2017). Sumber informasi adalah media yang berperan penting untuk seseorang dalam menentukan sikap dan keputusan untuk bertindak. (Notoatmodjo, 2003)berpendapat sumber informasi adalah segala sesuatu yang menjadi perantara dalam menyampaikan informasi, media informasi untuk komunikasi massa. Sumber informasi dapat diperoleh melalui media cetak (surat kabar, majalah), media elektronik 
(televisi, radio, internet). Informasi yang diperoleh dari beberapa sumber akan memengaruhi tingkat pengetahuan petani. Seorang petani yang banyak memperoleh informasi cenderung memiliki pengetahuan yang lebih luas. (Rogers, 1983) menyatakan bahwa sumber informasi memengaruhi kelima komponen (self efficacy, respon effectiveness, severity, vulnerability, dan fear) yang kemudian akan mendapatkan salah satu dari adaptive coping response atau maladaptive coping response. Teori tersebut menyatakan bahwa semakin seseorang mendapatkan informasi dari berbagai sumber maka kecendrungan seseorang akan mengambil sikap yang baik pula mengenai sesuatu hal.

Nilai $p$-value variabel akses informasi sebesar 0,00<0,05 (taraf nyata 5\%) yang menunjukkan H0 diterima, artinya variabel faktor akses informasi memberikan pengaruh yang signifikan dan dapat memengaruhi petani swadaya dalam penerapan sertifikasi keberlanjutan. Hasil uji regresi logit terhadap variabel akses informasi memiliki nilai koefisien positif sebesar 2,045. Variabel akses informasi dalam penelitian ini memiliki nilai Odds Ratio paling tinggi daripada variabel yang lainnya, dapat disimpulkan variabel ini adalah faktor yang paling berpengaruh untuk petani swadaya dalam menerapkan sertifikasi keberlanjutan perkebunan kelapa sawit. Nilai Odds Ratio variabel akses informasi yang dihasilkan sebesar 7,729 artinya jika akses informasi yang diterima petani swadaya bertambah 1, maka peluang kemungkinan petani swadaya dapat menerapkan sertifikasi keberlanjutan naik sebesar 7,729.

Dari hasil pengamatan di Kecamatan Secanggang, biasanya petani swadaya memperoleh informasi dari media sosial, media elektronik, media cetak, informasi antar petani (mouth to mouth), bandar/tengkulak/agen, formulator pestisida, sales pupuk dan pemilik Pabrik Kelapa Sawit (PKS). Penelitian yang dilakukan oleh (Sibarani et al., 2015) menyebutkan bahwa akses informasi merupakan tantangan yang dihadapi petani swadaya di Desa Air Hitam, Kabupaten Pelalawan dalam menghadapi sertifikasi ISPO. Maka dapat disimpulkan jika akses informasi sangat dibutuhkan petani swadaya sebagai gambaran tentang sertifikasi keberlanjutan perkebunan kelapa sawit. 


\section{KESIMPULAN DAN SARAN}

\section{Kesimpulan}

Faktor internal yang dapat memengaruhi penerapan sertifikasi keberlanjutan perkebunan kelapa sawit di kalangan petani swadaya di Kecamatan Secanggang adalah Umur Petani, Pengalaman Bertani Kelapa Sawit, Jumlah Tanggungan Keluarga dan Pendapatan Usahatani Kelapa Sawit, sedangkan faktor eksternal yang dapat memengaruhi penerapan sertifikasi keberlanjutan perkebunan kelapa sawit adalah Akses Informasi.

\section{Saran}

Saran penelitian membentuk Koperasi yang diinisiasi oleh Pemerintah Daerah Kabupaten Langkat yang berguna menaungi Petani Swadaya dalam kegiatan usahatani kelapa sawit guna meningkatkan taraf hidup petani swadaya di Kecamatan Secanggang.

\section{DAFTAR PUSTAKA}

Agustina, D., \& Hariyadi. (2014). Analisis Lingkungan Sosial, Ekonomi Pengelolaan Perkebunan Kelapa Sawit Berkelanjutan Berdasarkan Kriteria ISPO PT. Tapian Nadenggan. Jurnal Pengelolaan Sumberdaya Alam Dan Lingkungan, 4(1), 43-48.

Akhbianor, Normelani, E., \& Anggriani, P. (2015). Strategi Petani Swadaya Kelapa Sawit Dalam Mengelola
Perkebunan Kelapa Sawit Di Desa Sungai Kupang Jaya Kecamatan Kelumpang Selatan Kabupaten Kotabaru. JPG (Jurnal Pendidikan Geografi, 2(2), 1-15.

Andoko, Agus, \& Widodoro. (2013). Berkebun Kelapa Sawit si Emas Cair. PT. Agro Media Pustaka.

Brandi, C., Cabani, T., Hosang, C., Schirmbeck, S., Westermann, L., \& Wiese, H. (2015). Sustainability Standards for Palm Oil. Journal of Environment \& Development, 24(3), 292-314.

Dharmawan, A. H., Nasdian, F. T., Barus, B., Kinseng, R. A., Indaryanti, $\quad \mathrm{Y}$., Indriana, $\mathrm{H}$, Mardianingsih, D. I., Rahmadian, F., Hidayati, H. N., \& Roslinawati, A. M. (2019). Kesiapan Petani Kelapa Sawit Swadaya dalam Implementasi ISPO: Persoalan Lingkungan Hidup, Legalitas dan Keberlanjutan. Jurnal Ilmu Lingkungan, 17(2), 304-315. https://doi.org/10.14710/jil.17.2.30 4-315

Emilia, R., Hutabarat, S., \& Arifudin. (2014). Faktor-Faktor Yang Memengaruhi Minat Petani Kelapa Sawit Rakyat Berpartisipasi Dalam Sertifikasi Produk Di Kabupaten Kampar. SEPA, 11(1), 142-150.

Ginting, M. C. D. (2016). Analisis Pendapatan Dan Faktor-Faktor Yang Memengaruhi Penerapan Usahatani Padi Sehat Di Kecamatan Cigombong Kabupaten Bogor. Institut Pertanian Bogor.

Gustina, Y., Chozin, M., \& Barchia, M. F. (2020). Analisis Komparasi Usahatani Padi Dan Usahatani Kelapa Sawit. Jurnal Penelitian Pengelolaan Sumberdaya Alam Dan Lingkungan, 9(1).

Hendayana, R. (2013). Application Method of Logistic Regression Analyze the Agricultural 
Technology Adoption. Informatika Pertanian, 22(1), 1-9.

Hosmer, D. W., \& Lemeshow, S. (2000). Applied Logistic Regression (2nd ed.). John Willey and Sons.

Mandang, M., Sondakh, M. F. L., \& Laoh, O. E. H. (2020). Karakteristik Petani Berlahan Sempit Di Desa Tolok Kecamatan Tompaso. Agri-Sosio Ekonomi, 16(1), 105-114.

Nora, S., Manullang, W., \& Wijoyo, H. (2020). Evaluasi Kesesuaian Lahan Tanaman Kelapa Sawit Di Kecamatan Secanggang Kabupaten Langkat Provinsi Sumatera Utara. Jurnal Agrica Ekstensia, 14(1), 11.

Notoatmodjo, S. (2003). Pengembangan Sumber Daya Manusia. PT. Rineka Cipta.

Nurfitri, I. (2014). Tingkat Adopsi Teknologi Budidaya Sayuran Organik Oleh Petani Mitra Ads-Uf Ipb Serta Faktor-Faktor Yang Memengaruhinya. Institut Pertanian Bogor.

Pahan, I. (2007). Panduan Lengkap Kelapa Sawit. Penebar Swadaya.

Panjaitan, E., Paman, U., \& Darus. (2020). Analisis Pengaruh Faktor Produksi Terhadap Produktivitas Usahatani Kelapa Sawit Pola Swadaya Di Desa Sungai Buluh Kecamatan Kuantan Singingi Hilir, Kabupaten Kuantan Singingi. Dinamika Pertanian, 36(1), 61-68. https://doi.org/10.25299/dp.2020.vo 136(1).5371

Putri, C. F. A., \& Purnomo, N. H. (2017). Faktor-Faktor Pengambilan Keputusan Petani Untuk Budidaya Melon Di Kecamatan Tanjunganom
Kabupaten Nganjuk. Swara Bhumi, 04(5), 7-14.

Rizal, A., Hamidah, S., \& Wuryani, S. (2018). Analisis Penerapan Sertifikasi. Universitas Mercu Buana Yogyakarta, 7.

Rogers, E. M. (1983). Diffusion of Innovations (3rd ed.). The Free Press.

Rosni. (2009). Penurunan Kualitas Ekosistem Mangrove Hubungannya Dengan Pendapatan Masyarakat Nelayan Di Kecamatan Secanggang Kabupaten Langkat Provisnsi Sumatera Utara. Jurnal Geografi, 1(1), 13-26.

Saragih, I. K. (2020). Analisis Status Keberlanjutan Perkebunan Kelapa Sawit Rakyat Provinsi Jambi. Institut Pertanian Bogor.

Sibarani, D. Y. T., Hutabarat, S., \& Dewi, N. (2015). Prospek Dan Tantangan Petani Kelapa Sawit Swadaya Di Desa Air Hitam Kecamatan Ukui Kabupaten Pelalawan Dalam Menghadapi Sertifikasi Ispo. Jom Faperta UR, 2(1), 15.

Soekartawi. (1988). Prinsip Dasar Komunikasi Pertanian. Penerbit Universitas Indonesia (UI-Press).

Soekartawi. (2003). Agribisnis Teori dan Aplikasinya. PT. Raja Grafindo Persada.

Supriana, T. (2010). Social-Economic Aspects Of Coastal Community That Influence Mangrove Forest Degradation In Secanggang Village Langkat Regency. Jurnal Bumi Lestari, 10(1), 91-97. 